\title{
Role of leasing for sustainable development of the Russian economy
}

\author{
Vera Gerasimova ${ }^{1 *}$ \\ ${ }^{1}$ Moscow State University of Civil Engineering, Yaroslavskoe shosse, 26, Moscow, 129337, Russia
}

\begin{abstract}
This article suggests a deeper insight into the basic trends in Russian economy and national leasing market in view of acute shortage of investment and slumping oil prices. The Russian macroeconomic situation is not favorable for the leasing market development. A key attention is dedicated to leasing market which is a key indicator of the Russian economy. Leasing is looked upon as an effective means of business support and a powerful tool of sustainable development, as well as a way of acquiring credit income and renewing main capital. At this stage of Russian economy development, it is essential to work out the proper order of transactions and the Central Bank suggests that the leasing business should draw amendments to the existing regulations in order to create new control standards for leasing operations. It appears to be critical to enable a lessor to make flexible and effective administrative decisions and enjoy the possibility of managing the risks and profits of leasing transactions. The article also explains the correlations between external and internal economic factors, between financial and operative forms of leasing, between the amount of leasing investments and their contribution to the socio-economic revival of Russia.
\end{abstract}

\section{Introduction}

The downward trend in Russian economy started in June 2014 and deepened in 2015. The falling domestic demand, acute shortage of investment, slumping oil prices, weakening rouble - all these factors had a negative impact on the Russian economy. GDP contracted $3.7 \%$ in $2015,0.2 \%$ in 2016 , compared to $0.6 \%$ GDP growth in 2014 . Industrial production fell $4.8 \%$ in the first half of 2016 and $4.5 \%$ by the end of that year. The fall in the retail business reached $9.2 \%$ in the first half of 2015 and $15.3 \%$ by the end of the same year. Inflation reached $12.9 \%$ by the end of 2015 - the highest since the economic crisis of 2008. The slump in oil prices devalued the rouble which lost half of its value to the US dollar. The Russian Central Bank cut the key rate seven times - from 17\% in December 2014 to 10\% in September 2016 - another factor that reduced the rouble value. In 2017 Rosstat has reported about GDP growth of the Russian Federation for 1,5\%. Inflation in Russia in 2017 has made $2,5 \%$. The index of physical volume of gross domestic product in the III quarter 2017 of rather corresponding period of 2016, by preliminary estimate, has

\footnotetext{
* Corresponding author: angela-1309.m@yandex.ru
} 
made 101,8\%" - specifies Rosstat. The Russian economy has stagnated for the last 8 years, with average GDP growth at $0.2 \%$ from 2009 to 2016. The Finance Ministry has used the Reserve Fund three times this year to keep the economy afloat. In 2008 the Reserve Fund comprised $\$ 137.09$ billion and the National Wealth Fund, \$87.97 billion. From July 2014 to September 2016, National Wealth Fund shrank by $\$ 15.26$ billion, from $\$ 87.97$ billion to 72.71 billion. Russia's Reserve Fund has come under increasing strain as the country's oildependent economy has suffered under falling energy prices. In a single month of August 2016 Russia spent $18.4 \%$ of its Reserve Fund to plug deficits in Federal Budget, Finance Ministry revealed on September 6, 2016. Unfortunately, behind such sharp increase in quantity of means in 2016, their not less sharp recession has followed [1].

\section{Methodological approaches and analysis}

The purpose of this article is to describe fluctuations and trends in the evolution of the Russian leasing market and its main sectors within the last three years and to determine their potentialities and impacts on the Russian economy. The article is also aimed at explaining the correlations between external and internal economic factors, between financial and operative forms of leasing, between the amount of leasing investments and their contribution to the socio-economic revival of Russia. The expert assessments of the state of Russian economy are included to provide a much broader understanding of the leasing market. The article uses the scientific method of economic analysis, both descriptive and analytical, deductive and inductive. It provides quantitative statistical data analysis and important correlations to establish the cause-and-effect relation between different variables. The Russian macroeconomic situation was not favorable for the leasing market development. A rather pessimistic situation is taking place in the area of consumer demand which is the most important factor for leasing companies. The leasing market, which is a key indicator of the Russian economy, has been quite unstable: its abrupt ups and downs indicate that it is still underdeveloped and insufficiently regulated by the Russian government. The compulsory licensing of the leasing market was introduced in 1995 and enacted till 2002. And although some leasing companies are state-regulated, they may not be fully considered as an integral part of the business market. Up to 2012 the leasing market was growing at the rate of $30 \%-70 \%$ depending on a sphere of its business, but the economic slump of 2015 caused a slowdown in leasing activity, which most strongly affected the Railway business. Both Railway and Aviation leasing shrank significantly, weakening leasing business, as a whole: it was the first time in the last decade when the Russian economy entered the downturn cycle. But further contraction of the market was avoided by means of large investments into aviation sector and preferential subsidies, the measures which will have a much greater significance for the development of leasing business. According to the statistical data of Expert RA, the volume of this business amounted to 275 billion roubles within the first half of 2016 (13\% increase compared to 2016 when the leasing business shrank over $75 \%$; since the second half of 2016 , a fairly stable financial market, mainly its banking sector banks were closed in 2016 and 48 banks in the first half of 2017 as part of a difficult cleansing process], had a positive influence on lease transactions) $[1,2,3]$.

In 2016 it became increasingly obvious that the sanctions imposed on Russian economy would not be lifted in the near future and to preserve the steady money influx from business it was necessary to increase its capital. On the other hand, the sanctions sped up the development of different spheres of Russian economy and a new trend to replace imports with home products has led to more complex ways of cooperation between a lessor and a client and has allowed the creation of new investment projects. Moreover, the Government 
learned to use leasing as a stimulus for the investment into its main capital. Yet, the paradox of this situation consists in the fact that, somehow, the leasing market remains the only one not yet regulated by the Central Bank. The Russian financial market has been quite turbulent lately and its future depends on the capacity and determination of shareholders to make investments and on the capacity of leasing companies to secure a return on their investments at $12-16 \%$ annually. The shareholders who make the decision to invest into the bank capital or into a leasing company are concerned with the security of their investments $[4,5]$.

The leasing market is currently undergoing the process of merging - smaller companies are being driven out mainly due to the insolvency of their clients. The Railway companies are facing difficult situation - they are forced to reduce the costs of their transportations to retain clients who, otherwise, will resort to automobile services. Automobile leasing and special equipment leasing find themselves in a better situation - they have been receiving substantial subsidies since 2016 and concentrate their efforts not on leasing new equipment but on leasing the used equipment confiscated from their debtors. Not even the slump in car sales due to the decline in purchasing power, nor the increase in car prices affected Autoleasing significantly - it withstood all negative impacts and won the leading position on the market thanks to the state support, the introduction of express-products, and offering discounts to clients [6].

Aviation leasing, the biggest sector of the leasing market, fell 18\% in 2016 and a number of Russia's largest leasing companies incurred substantial financial losses due to the bankruptcy of Transaero Aviation Company. The Government subsidies prevented its further fall and it remains the leader in this sphere of business - its share reached $36 \%$ in 2015 and $37 \%$ in 2016 [7]

Leasing is looked upon as an effective means of business support and a powerful tool of industrial development, as well as a way of acquiring credit income and renewing main capital. It contributes to technical modernization and economic revival, and requires the restructuring of budget expenses. In other words, it is a profitable form of private investment. The main objective of the leasing companies is to minimize expenses while expanding and strengthening their business. Leasing market is a good indicator of investment activity in economy - its negative indicators reveal the reduction of business activity in different spheres and of economic activity, as a whole: bankruptcy of small business, growing unemployment, contraction of industry, etc.

\section{Results and Discussion}

A high degree of economic uncertainty in Russia causes instability and frequent fluctuations in investment business. The preliminary report of the $\mathrm{CB}$ indicates that the investments into the main capital within January-March 2016 amounted to 16, 6 billion roubles, the $0,7 \%$ drop compared to the same period of 2015 . The main capital lost $20 \%$ of its value due to the negative impact of external economic and political factors and the state of Russian economy made it abandon the renewal of its industrial capacity. The financial and operative leasing transactions fell $17 \%$ (to 830 billion roubles), compared to the previous year, and the total amount of the received leasing payments outgrew the amount of the investments, which impacted financial portfolio [8].

A powerful trend in 2015-2016 has been a shift from financial to operative leasing which provides opportunities for small to medium business to make use of costly equipment which they cannot effort. However, if we move from financial to operative leasing, we will run the risks of dealing with equipment deterioration, financial losses due to the falling demand, increasing extra-production expenses or the breakdown of equipment. This trend to operative leasing has been most evident in Air transportation. Yet, 
it will be wrong to consider operative leasing as a unique type of anti-crisis measure. Returnable lease is also effective under money shortages - this type of transaction allows a lessor to improve his financial condition by simultaneously selling and leasing his equipment. Under extreme shortage of money another type of leasing - Compensational can be quite useful. In this leasing, the payments are made by means of product supplies manufactured with the equipment which is the object of lease transaction [9].

In 2016, the leasing companies shifted their priorities from broader specialization to concentrating on the spheres of their major experience. The volume of the used equipment continues growing, partially due to the insolvency of clients and its technical condition should be regularly assessed prior to being auctioned. In the absence of demand the used equipment is sold out at lower prices. The demand for new equipment fell significantly compared to the pre-crisis period, nevertheless, the demand for special equipment and cargo transportation stays high. To stimulate the demand, the leasing companies offer discounts and the possibility of installment payments, but this strategy has its drawbacks: on one hand, it attracts clients, on the other hand, it deteriorates the quality of their portfolio. Yet, if a decrease in the quality of a leasing portfolio is inevitable, there is a returnable lease which helps refinancing the debt of the client company on the security of property. It is evident that such transactions do not contribute to the growth of new business, but effectively cover the budget shortages of leasing companies [10].

At this stage it is important to work out the proper order of transactions and the Central Bank (CB) suggested to the leasing business to draw amendments to the existing regulations in order to create new control standards for leasing operations. A new draft of the law was issued and discussed in December 2015, and the leasing companies were offered the status of non-credit financial organizations. The functions of $\mathrm{CB}$ - licensing, notification, delegation and surveillance - were brought to discussion, as well. The existing judicial problems were a serious obstacle to the reduction of the leasing companies' expenses, and finding efficient solutions will stimulate their further development. And although CB makes considerable efforts for the development of leasing in Russia, it is not yet the essential infrastructure to attract investment and protect investors' rights. The lack of leasing options for individuals is a serious drawback in this business. If the abovementioned new draft of the law is considered workable, leasing regulations will be conducted with the minimal interference from the Government by upholding competition and reducing the costs of funding, which will make leasing business highly efficient [11].

For the last few years, the placement of bonds has been one of the major means of funding the leasing companies as it does not require transaction security and helps diversify financial resources. Leasing investments, as a major anti-crisis measure, influence the development of this business and allow the state to consolidate diverse sectors of economy. As the examples of this business activity, we have a pioneer program of Preferential leasing, financing the lease of Russian aircraft, subsidizing the private reimbursement of credit expenses, as well as the program "The Funds for Industrial Development" sponsored by industrial business - the key factor in the lease of advanced technology within 20182019.

Not all the leasing spheres are direct competitors - each sphere has its own peculiarities, advantages and drawbacks, and each sphere has its own clients. Good examples are Railway, Air and Water transports. What characterizes the Russian market as a whole is its indebtedness, which is the highest in the Railway sphere and somewhat less in Air and Automobile transportation. Navigation leasing companies require long-term credits to cover their expenses of ship-building (it takes 1-2 years to build a ship and at least 10 years to repay the loans). For a potential lessor-shipholder it is extremely important to know the terms of leasing and its duration. Compared to the construction business where the main expenditures go into construction materials, the essential part of the navigation business 
capital goes into the wear-and-tear payments. And yet, despite all the complexities of the shipping business, it grew twofold.

If we speak of Classical leasing, it is an agreement intended to cover the full costs or most of them, extra expenses and lessor's profit during the whole period of leasing. Classical leasing is very similar to credit, the difference consists in the fact that until a lessee pays back his debts, the leasing property belongs to a leasing company.

"In my opinion, today's statements that financial leasing is close to stagnation are not true. Worldwide, financial leasing is an important part of financial sphere. The market is evolving and we are moving into the phase when the companies are searching for new markets, spheres, clients, higher profits and offering more refined and elaborate products."

Litovkin Oleg, former Director General of UralSib LC in 2016, states that leasing market has insufficient capital and requires new judicial regulations. "Our operative leasing is based, to a great extent, not on the Russian legislation, but on the foreign one. Each of our regions has its own understanding of leasing and its transactions. Some economic experts consider the investment of capital into financial sphere highly risky due to the impossibility of securing the level of profits expected by shareholders - a lessor does not expect to regain all his expenses through lease payments from one lessee. A lease agreement is made for 2-5 years, which is considerably shorter than the wear-and-tear period of equipment. The risk of damage and loss of equipment is responsibility of a lessor. In this sphere of leasing the payment rates are higher than in financial leasing which is determined by the fact that a lessor has no full guarantee of the recoupment of his expenses, and that is why he has to take into account all commercial risks: the risk of not finding a lessee, the risk of the breakdown of equipment, the risk of canceling the agreement and, thus, he has to charge more for his services. In operative leasing, the company acquires the equipment prior to knowing its lessee, therefore, this company must be well-aware of all the workings of the investment markets. This company has to assure the property it leases and provide it with technical support." (Litovkin Oleg was Director-General of UralSib LC from May 2009 to March 2016; in 2008, UralSib was the biggest and most reliable company in Russia; in mid-2014 the losses of the company amounted to 1, 18 billion roubles and in mid-2015, to 2, 88 billion roubles)

Kalinkin Maxim, Vice-president of Gazprombank Leasing, sees operative leasing as a driving force of the market and its advantages in the implementation of newest technologies and equipments. The clients in this sphere of leasing do not order new equipment but use the equipment they have and make profit right away. The demand for this kind of lease comes from three sectors: aviation, railway and automobile transport. The clients in this sphere are many and the lessors should take into account their financial capacities and possible risks. The restraining factors in this leasing are lack of sufficient experience and competence. The confiscation of the lease property is not so critical as the confiscation of the equipment and its further use - how to maintain and resell it, and how to assess its residual value.

Lukovsky Vyacheslav, Chief Manager of the Autotransport Company Baltic Leasing: "The main and most common means of funding commercial autotransport is financial leasing, with subsequent transference of the property to a lessee. This is the most essential part of Baltic Leasing portfolio and we regularly create new financing programs to support small and medium business; our program "Targeted Leasing" is nowadays the most profitable of all leasing market services."

Derek Soper, Chairman IAA- Advisory: "With the huge changes in the world's financial landscape it would be easy to assume that the leasing product has changed, as well. There are three major changes to the leasing market which have taken place as a result of the financial crisis and the current pressures on the banking system. I would describe them as capital allocation, survival and costs, and re-establishing-re-connecting-and 
retaining the customer base. Leasing has always been a method of obtaining the use of equipment rather than a method of purchasing it" $[12,13]$.

Vahid Daemi, CEO of LeasePlan: "After a few years of strengthening performance, leasing indicators are now seeing an initial negative reversal. Despite strong growth in new business volume and outstanding portfolios, the leasing industry is experiencing struggling financial KPI's in Q2 2016. The root of this issue appears to be growing loan loss provisions, although income also remains weak. Although it is difficult to speak with any certainty, the run-up to the Brexit vote at the end of Q2, in addition to other headwinds affecting the European economy, are likely to have had a stifling effect on businesses and investment. Whether this is a temporary lapse or the beginning of a more long-term trend, the leasing business will need to remain alert and agile moving forward."

Leasing is becoming an intellectual capital. In the highly-industrialized countries it comes second in the volume of investment after bank credits, that is, leasing is one of the main investment means into economy. One of the major concerns of the lessors is financial risk management and its efficiency is determined by:

1. The capacity of a lessor to make flexible and effective administrative decisions.

2. The possibility of managing the risks and profits of leasing transactions

The questions that arise before the expert lessors are: how to develop their service, what to offer their clients, where to move leasing industry and, first and foremost, to have a clear and comprehensive analysis of macroeconomic trends $[14,15]$.

Leasing transactions should meet the demands of both, a lessor and a client, reduce contradictions between them, and allow lessees to make use of the costly equipment which is the powerful means of economic development. The importance of leasing in Russia is determined by the critical condition of the industrial equipment due to money shortages -outdated equipment and its low effectiveness are a great impediment to the economic development of the country. It is the close link between the lessors and equipment producers that makes the leasing market fast-growing and international. If the best economic expectations come true the total volume of the leasing market will amount to 450 billion roubles or $10 \%$ up from its volume in 2015 .

\section{Conclusion}

Rosselmash-Finance and DLL Leasing signed the cooperation agreement which will allow the Russian farmers to buy farm machinery on unprecedented conditions. RosselmashFinance launched one of the most profitable of its proposals for agricultural producers Ultra Leasing which has a number of unique advantages: the leasing contracts for five years, with the possibility of prolongation for two years more; the package of special programs of preferential financing on the best terms; high-quality agricultural machinery, etc. Both companies are leaders in their sectors and the agreement is aimed at supporting Russian farmers - DLL Leasing Company will transfer in leasing more than 500 snow removal vehicles and other equipment.

1. In 2016, the Bank of Russia carried out the study of the leasing market based on the survey of leasing companies. The basic indicators of the market players' activity were taken into account. Companies were selected for the study by the size of their leasing portfolio. Out of 50 major companies, 26 responded to the Bank of Russia's inquiry and the questionnaires received about $60 \%$ of the estimated value of the leasing market. Therefore, the sector remains non-transparent. Growth of new business of the companies in 2018 expect $84 \%$ of representatives of the market.

2. Railway and Air Transportation equipment continue to hold leading positions in the total leasing portfolio ( $39 \%$ and $28 \%$, respectively). The new business structure is demonstrated by the agreements on the lease of railway equipment (32\%) and air 
transportation equipment (20\%), cars and freight transport (19\% each). Acquisition of freight cars and local passenger trains by leasing operators will become the market driver.

3. Aircraft leasing is the only major segment that demonstrated growth in 2017 - the positive dynamics of this sector can be attributed to the government's policy of subsidizing the Russian producers of airliners. According to the data of the surveyed companies, the volume of restructuring in the lease market grew in 2017 compared to 2016 (from 2.5 billion roubles to 47.5 billion roubles). The volume of assets sold during this period increased by $30 \%$. According to White Clarke Group Global Leasing Report (2016), Russia is placed $11^{\text {th }}$ in the world by the volume of leasing business and $2^{\text {nd }}$ among emerging market economies (after China).

4. The Leasing Strategy for the Future. The annual Congress of the leasing industry took place in St. Petersburg, organized by the United Leasing Association of Russia and supported by the European Confederation of Leasing Associations (LeaseEurope). The aim of the Congress was to create a strategic plan - the Leasing strategy till 2020 - which will be conducted by the groups working in the major segments of the leasing market. After the Congress, ULA published a series of articles on the development of leasing market in Russia. The Russian leasing business maybe down, but not out.

\section{References}

1. Russia in figures (Rosstat, Moscow, 2017)

2. David G. Mayer, Business Leasing and Finance News, 74 (2008)

3. D. Powell, Asset-based financing, investment and economic growth, The Centre for Spatial Economics (Milton, Ontario, 2004)

4. M. Adams, M. Moskovitz, R. Brown, C. Stein, Office Leasing: Drafting and Negotiating the Lease, (Publisher: Continuing Education of the Bar-California, 1996)

5. S. Amembal, S. Halladay, A Guide to Accounting for Leases, (Amembal, Halladay \& Isom, Salt Lake City, 1992)

6. K. Brown, Leasing Handbook: 12 Things You Must Know About Leasing a Car, Leasing Finance and Leasing Equipment (Kindle Edition, 2015)

7. S. McMichael Long Term Land Leaseholds: Including Ninety-Nine Year Leases (Nabu Press, 2014)

8. E. Vasilyeva, I. Polyakova, Economy and entrepreneurship, 4-2 (81-2), 1024-1028 (2017)

9. E. Vasilyeva, I. Polyakova, Krasnoyarie Science, 6 (3-2), 130-134 (2017)

10. A. Mottaeva, IOP Conference Series: Earth and Environmental Science, 90(1), 012124 (2017)

11. A.V. Gerasimova, O.N. Zotikova, Fibre Chemistry, 2, 87-88 (2016 )

12. I. Polyakova, E. Chibisova, Economy and entrepreneurship, 5 (70) 579-582 (2016)

13. Ch. Boobyer, Leasing Finance, (Euromoney Publications, 1997)

14. A. Mottaeva, J. Ćetković, Advances in Intelligent Systems and Computing, 692 11511159 (2018)

15. I. Polyakova, Construction economy, 4, 28-35 (2006)

16. M. A. Bahauovna, M. A. Bahauovna, International Journal of Applied Engineering Research, 11(9), 6808-6816 (2016) 